\title{
Studi Morfologi Dasar Laut dengan Survey Batimetri di Daerah Pantai Pasar Palik, Bengkulu Utara
}

\author{
Ashar Muda Lubis ${ }^{1 *}$, Nanda Sari, Rio Saputra ${ }^{1}$, Juhendi Sinaga ${ }^{1}$, \\ M. Hasanudin² , Edi Kusmanto \\ ${ }^{I}$ Jurusan Fisika, Fakultas Matematika dan Ilmu Pengetahuan Alam, Universitas Bengkulu \\ Jl. WR. Supratman, Kadang Limun, Muara Bangkahulu, Bengkulu, 38371 Indonesia \\ ${ }^{2}$ Pusat Penelitian Oseanografi, Lembaga Ilmu Pengetahuan Indonesia \\ Jl. Pasir Putih I, Ancol Timur, Jakarta 14430 Indonesia \\ Email: asharml@unib.ac.id
}

\begin{abstract}
Abstrak
Daerah Pantai Pasir Palik, Bengkulu Utara merupakan salah satu daerah dengan tingkat abrasi yang tinggi. Salah satu faktor pemicu cepatnya laju abrasi adalah morfologi dasar laut yang mempengaruhi tinggi gelombang yang sampai ke pantai. Tujuan penelitian ini untuk mengetahui bentuk morfologi dasar laut di daerah Pantai Pasar Palik dengan survey batimetri dan membandingkannya dengan data batimetri dari Badan Informasi Geospasial (BIG) resolusi 25 m, Earth Topography 1-Arc Minute Gird (ETOPO1) dengan resolusi $1850 \mathrm{~m}$ dan General Bathymetric Chart of the Ocean (GEBCO) resolusi $450 \mathrm{~m}$ dan $900 \mathrm{~m}$. Pengambilan data dilakukan dengan pemeruman menggunakan Single Beam Echosounder dan Global Positioning System (GPS). Koreksi pasang surut dilakukan dengan bantuan perangkat lunak wxtide4.7. Hasil penelitiaan menunjukkan pada pengukuran Echosounder kedalaman maksimum mencapai10 m, sedangkan data BIG maksimum $8 \mathrm{~m}$, GEBCO $450 \mathrm{~m}$ mencapai $55 \mathrm{~m}$, GEBCO $900 \mathrm{~m}$ mencapai $32 \mathrm{~m}$ sedangkan ETOPO1 hanya 2,67 m. Kemiringan morfologi dasar laut dikategorikan landai dengan nilai kemiringan $0,32^{\circ}$. Morfologi bawah laut di daerah pantai dapat dipengaruhi oleh faktor hidrografi dan oseanografi, maka penelitian lanjutan sangat diperlukan untuk melihat dinamika perubahan morfologi dasar laut.
\end{abstract}

Kata kunci : Morfologi, Batimetri, Kemiringan, Single Beam Echosounder

Abstract

Study on Morphology of Bottom Sea in Nearshore Pasar Palik Using Batimetry Survey

The Palik Coast area, North Bengkulu, is one of the area with high level of abrasion. One of the factors triggering the rapid rate of abrasion is the seabed morphology which affects the height wave energy near the coast. The purpose of this study was to determine the seabed morphology based on slope of seabed in Pasar Palik coast area with bathymetry survey, and also to compare the result with other bathymetry data; the BIG with resolution of $25 \mathrm{~m}$, ETOPO1 with resolution of $1850 \mathrm{~m}$ and GEBCO resolution of $450 \mathrm{~m}$ and $900 \mathrm{~m}$. The research was carried out by measuring bathymetry using Single Beam Echosounder and GPS. Tidal correction was conducted by using wxtide4.7 software. The result shows that the maximum depth reaches $10 \mathrm{~m}$ while the BIG data has the maximum depth of $8 \mathrm{~m}$. Maximum depth from GEBCO, GEBCO $900 \mathrm{~m}$, ETOPOI data is $55 \mathrm{~m}, 32 \mathrm{~m}$ and $2.67 \mathrm{~m}$ respectively. The slope of the seabed morphology is categorized as as declivous with a slope value of $0.32^{\circ}$. Morphology in coastal areas can be influenced hydrography dan oceanography factors, further research is needed to better understand the dynamics of morphology changes.

Keywords : Morfologi, Batimetry, Slope, Single Beam Echosounder 


\section{PENDAHULUAN}

Wilayah bagian barat Provinsi Bengkulu, terutama kawasan pantai sangat rentan terhadap gelombang air laut yang tinggi yang berasal dari Samudera Hindia. Pada kenyataannya pada beberapa dekade terakhir, wilayah pantai bagian barat Provinsi Bengkulu mengalami kerusakan yang sangat parah karena adanya proses abrasi pantai (coastal erosion) yang berlangsung dari waktu ke waktu (Gambar 1). Pada 10 tahun terakhir, beberapa desa di Bengkulu Utara sudah hilang karena tererosi beberapa puluh meter dari garis pantai sebelumnya. Penelitian terakhir oleh Lubis dan Rida Samadara, (2016) memberikan informasi bahwa kecepatan abrasi maximum mencapai $25 \mathrm{~m} /$ tahun, dan sudah menghilangkan beberapa desa di daerah Bengkulu Utara. Hasil penelitian ini sangat memprihatinkan mengingat banyak wilayah pantai yang tererosi dan besarnya perubahan garis pantai selama 30 tahunan terakhir.

Perubahan garis pantai karena abrasi di Kabupaten Bengkulu Utara ini telah memutuskan setengah badan jalan di beberapa titik dimana jalan tersebut merupakan jalan lintas utama penghubung kabupaten dan kota. Selain jalan lintas, abrasi juga telah menghilangkan lahan kelapa sawit warga. Jika hal ini terus dibiarkan dampak terbesar dari abrasi tersebut dikhawatirkan akan menghabisi pemukiman penduduk. Abrasi yang terjadi di Kabupaten Bengkulu Utara terbagi menjadi beberapa wilayah dengan kecepatan yang berbedabeda satu sama lain. Salah satu wilayah yang rusak parah akibat abrasi pantai adalah daerah pantai Pasar Palik, Lais Bengkulu Utara (Gambar 1).

Secara teori, abrasi pantai umumnya terjadi karena gejala alam baik itu karena perubahan iklim yang menimbulkan peristiwa ektrim pasang surut,

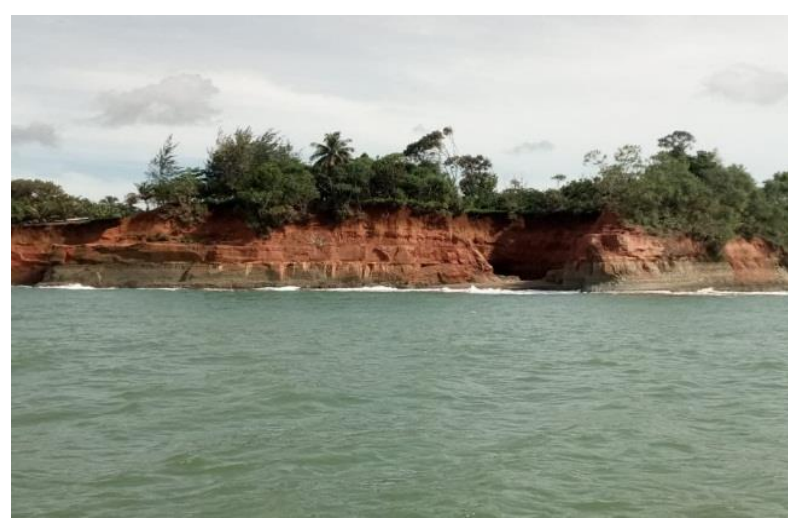

tinggi gelombang laut atau pun kenaikan permukaan laut karena pemanasan global, atau abrasi juga bisa terjadi karena pengaruh tektonik yaitu perubahan permukaan tanah pada daerah pantai maupun karena proses sedimentasi di daerah muara sungai (Sunamura, 2015). Tinggi gelombang dan besar energi yang sampai kepantai tidak lepas dari pengaruh morfologi dasar laut perairan. Pada pantai yang bermorfologi dasar laut miring (kemiringan di atas $5^{\circ}$ ), run up gelombang sebagian besar energinya akan diteruskan ke arah pantai sebagai arus sejajar pantai (longshore current) dan kembali ke arah laut sebagai arus tegak lurus pantai (rip current), sedangkan pada pantai dengan morfologi dasar laut rata (kemiringan $0-2^{\circ}$ ) run up gelombang energinya sebagian besar akan hilang saat diteruskan ke arah pantai dan sisanya diteruskan sebagai arus sejajar pantai (Triatmodjo, 1999). Arus sejajar pantai dan arus tegak lurus pantai pada dasar laut dengan kemiringan di atas $5^{\circ}$ akan membawa material dari pantai saat kembali ke arah laut. Oleh karena itu penelitian bentuk dasar laut pada daerah pantai (morfologi dasar laut) sangat diperlukan. Penelitian ini dapat dilakukan dengan menganalisa data batimetri pada perairan setempat.

Pada saat ini telah tersedia beberapa data global batimetri yakni batimetri ETOPO1 (Amante and Eakin, 2009) dengan resolusi $1850 \mathrm{~m}$, data batimetri GEBCO dengan resolusi $900 \mathrm{~m}$ yang diluncurkan oleh British Oceanograpic data Centre (BODC) pada tahun 2008 (Weatherall et al., 2015), dan data global batimetri GEBCO dengan resolusi $450 \mathrm{~m}$ Tozer et al. (2019). Namun sampai saat ini data global batimetri tersebut masih memiliki resolusi yang tidak terlalu bagus

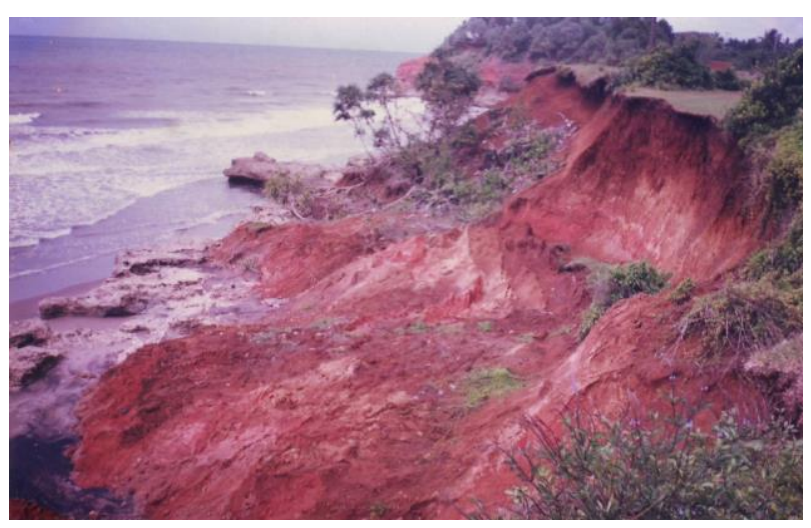

Gambar 1. Abrasi pantai di daerah Pantai Pasar Palik, Lais, Bengkulu Utara. 
sehingga tidak dapat menampakkan keadaan morfologi laut secara detail. Oleh karena itu penelitian batimetri secara lokal perlu dilakukan untuk mengetahui keadaan morfologi dasar laut dengan menggunakan data batimetri yang beresolusi tinggi, yaitu dengan melakukan pengukuran secara langsung menggunakan alat single beam echosounder. Penelitian dilakukan di daerah Pantai Pasir Palik, Bengkulu Utara untuk melihat morfologi dasar laut melalui perhitungan nilai kemiringan dasar laut di daerah Pantai Pasar Palik dan sekitarnya. Hasil penelitian yang diperoleh dibandingkan dengan data batimetri nasional BIG dan data batimetri secara global yang tersedia. Selanjutkan hasil penelitian ini juga akan bermafaat untuk input pada model penjalaran gelombang tsunami dan untuk informasi bagi nelayan setempat dalam rangka kegiatan pengembangan sektor perikanan laut dan pariwisata bawah laut.

\section{MATERI DAN METODE}

Pengambilan data batimetri di lapangan dilakukan di perairan sekitar Desa Pasar Palik, Bengkulu Utara pada November 2018 (Gambar 2). Pengambilan data kedalaman dilakukan dengan menggunakan alat Single Beam Echosounder Bathy 500 Dual Frequency dengan cara tracking sepanjang jalur penelitian pada koordinat $3^{\circ} 35^{\prime} 43,17^{\prime \prime} \mathrm{LS}$ dan $102^{\circ} 07^{\prime} 57,72^{\prime \prime} \mathrm{BT}$ sampai dengan $3^{\circ} 32^{\prime} 36,52^{\prime \prime} L S$ dan $102^{\circ} 01^{\prime} 36,76$ "BT. Pengukuran ini dilakukan koreksi kedudukan transduser terhadap muka air laut dan koreksi pasang surut. Koreksi poasang surut dilakukan menggunakan software Wxtide. Nilai koreksi yang didapat dari software Wxtide merupakan nilai berdasarkan persamaan koreksi pasang surut sebagai berikut (Soeprapto, 1999):

$$
\mathrm{rt}=\mathrm{TWLt}-(\mathrm{MSL}+\mathrm{Zo})
$$

Keterangan $: \mathrm{rt}=$ merupakan nilai kedalaman yang telah dikoreksi oleh pasang surut; TWLt = tinggi kedudukan muka laut pada waktu pengukuran; MSL = tinggi kedudukan muka air laut rata-rata; Zo = tinggi kedudukan muka surutan dibawah MSL.

Hasil pemeruman yang telah dikoreksi merupakan data tiga komponen yaitu $\mathrm{x}, \mathrm{y}$, dan $\mathrm{z}$ yang disimpan dalam bentuk tipe grid dimana $\mathrm{x}$ and y merupakan koordinat pada permukaan laut sementara $\mathrm{z}$ merupakan nilai kedalaman. Visualisasi morfologi bawah laut dilakukan dalam bentuk gridimage dengan menggunakan perangkat lunak ArcGis. Untuk melihat bentuk morfologi dasar laut, data batimetri ditampilkan dalam bentuk kontur kedalaman secara 3 dimensi (3D) dengan menggunakan bantuan perangkat lunak Surfer.

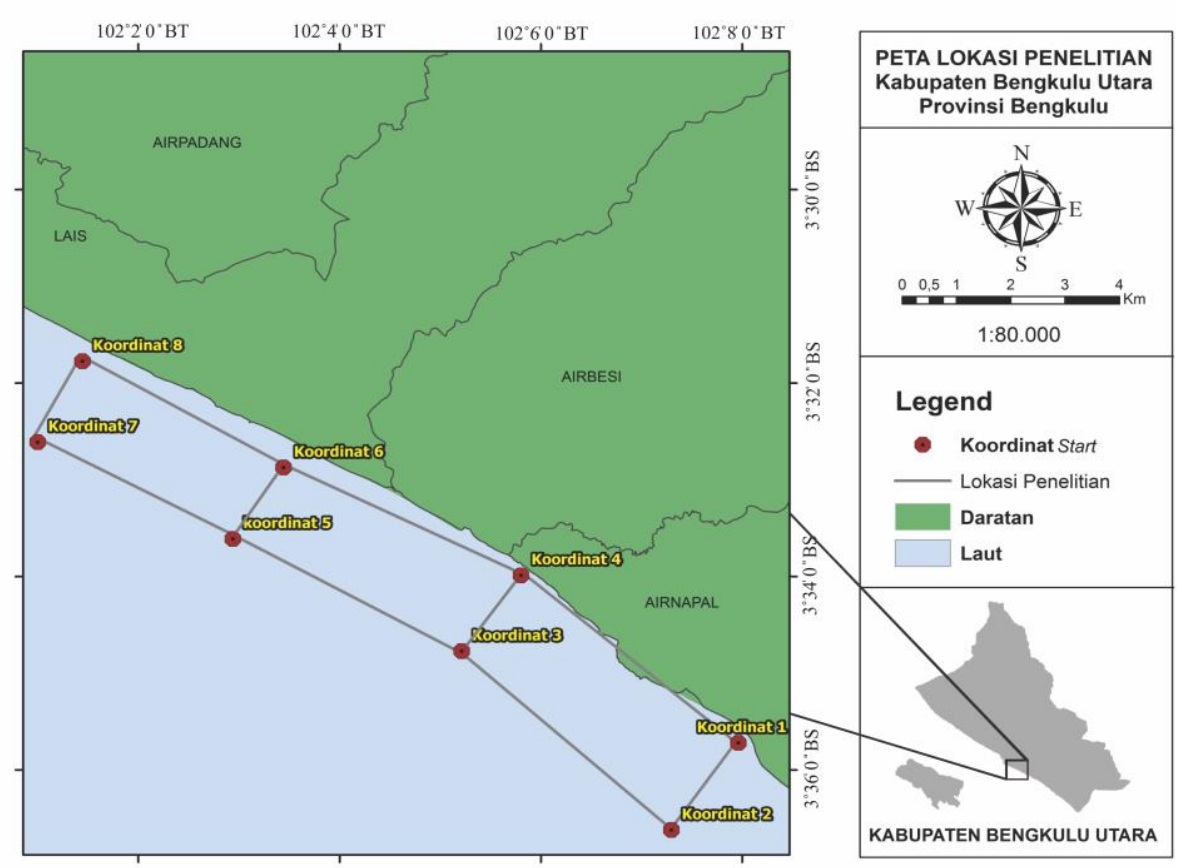

Gambar 2. Peta Lokasi Penelitian. 
Tabel 1. Klasifikasi kemiringan dasar laut.

\begin{tabular}{lc}
\hline Sifat & Morfologi $\left({ }^{\circ}\right)$ \\
\hline Datar hingga hampir datar & $0-2^{\circ}$ \\
Agak miring atau landai & $2-4^{\circ}$ \\
Miring dengan besaran yang tinggi atau bergelombang & $4-8^{\circ}$ \\
Agak curam & $8-16^{\circ}$ \\
Curam & $16-35^{\circ}$ \\
Sangat curam & $35-55^{\circ}$ \\
Curam sekali & $>55^{\circ}$ \\
\hline
\end{tabular}

Gambaran kemiringan dan kedalaman batimetri diperoleh dari 5 penampang sayatan (cross section) pada peta batimetri yang dihitung menggunakan persamaan sebagai berikut (Hutchinson, (1989); Abdallah et al. (2016)):

$$
\alpha=\tan ^{-1} \frac{\Delta \mathrm{h}}{\mathrm{L}}
$$

Keterangan : $\Delta h=$ elevasi antara beda ketinggian pada cross section yang diamati; $\mathrm{L}=$ jarak horizontal cross section yang diamati, tegak lurus terhadap beda ketinggian $\Delta h$.

Analisis morfologi dasar laut dilakukan berdasarkan kemiringannya Dengan menggunaka klasifikasi kemiringan dasar laut (slope) sebagaimana dikemukakan oleh Van Zuidam (1985), seperti tercantum pada Tabel 1. Hasil survey batimetri pada penelitian ini dibandingkan dengan data batimetri yang diperoleh dari BIG dan data batimetri yang tersedia secara global.

\section{HASIL DAN PEMBAHASAN}

Berdasarkan hasil pengukuran kedalaman laut pada daerah Perairan Pantai Pasar Palik, Bengkulu Utara, maka didapatkan data batimetri seperti diperlihatkan Gambar 3. Pada gambar ini diperlihatkan nilai kedalaman dasar daerah perairan mencapai $10 \mathrm{~m}$. Perairan Pantai Pasar Palik, Bengkulu Utara merupakan dataran pantai yang ke arah darat makin tinggi secara gradasi terlihat dari hasil pengamatan kedalaman yang makin dalam menuju laut lepas.

Pada Gambar 4 diperlihatkan kontur batimetri perairan pantai Pasar Palik, Bengkulu Utara secara 3D. Dari Gambar tersebut dapat dilihat bahwa morfologi dasar laut pada daerah selatan dari penelitian lebih landai jika dibandingkan dengan di bagian utara terutama memasuki daerah pertemuan antara perairan dan daratan.

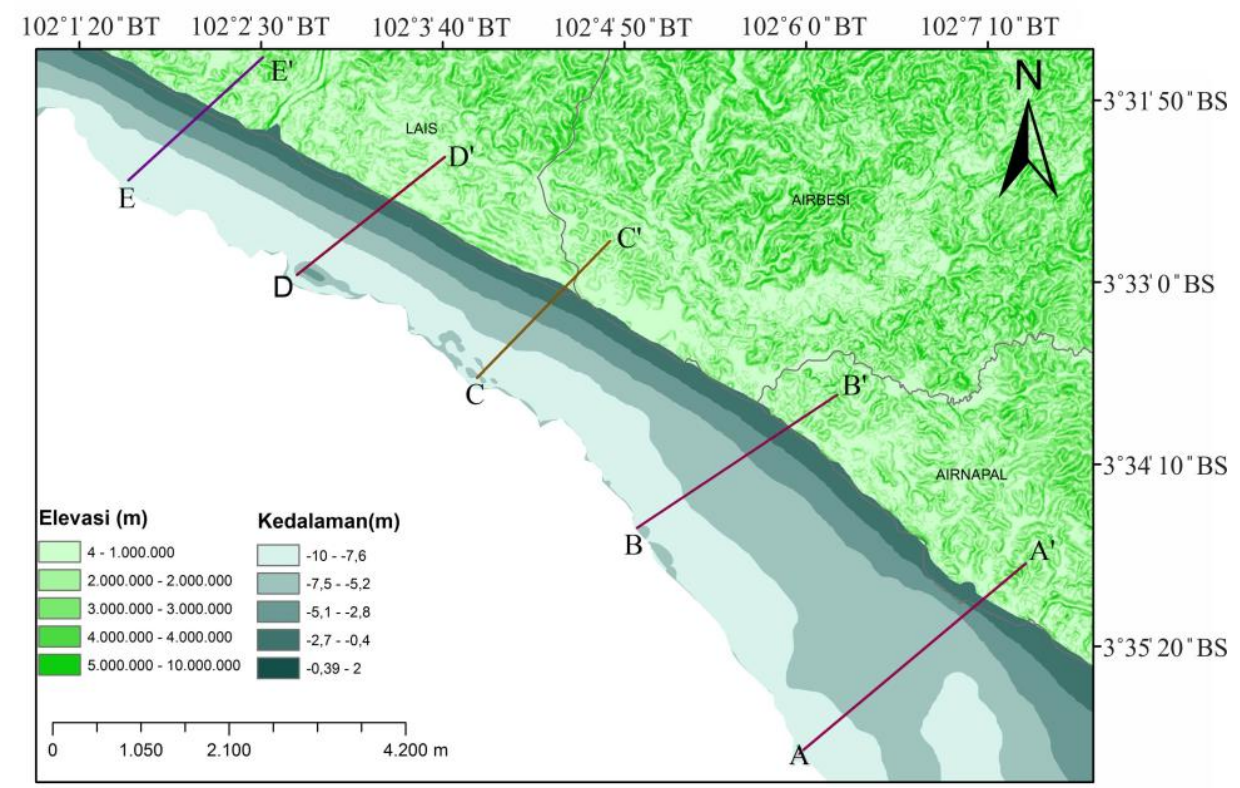

Gambar 3. Hasil image batimetri perairan Pantai Pasar Palik, Bengkulu Utara. 


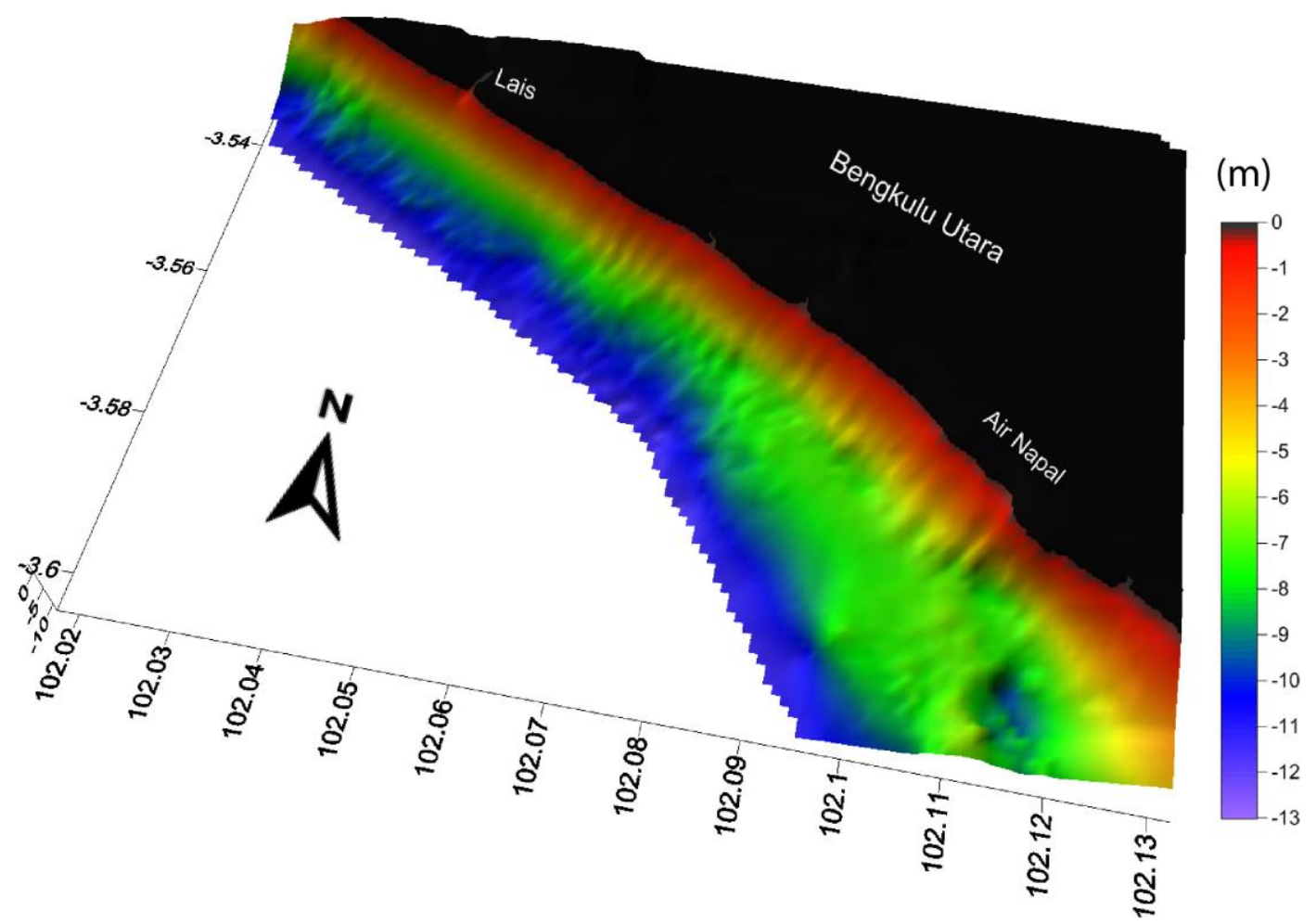

Gambar 4. Kontur batimetri perairan pantai Pasar Palik, Bengkulu Utara secara 3D.

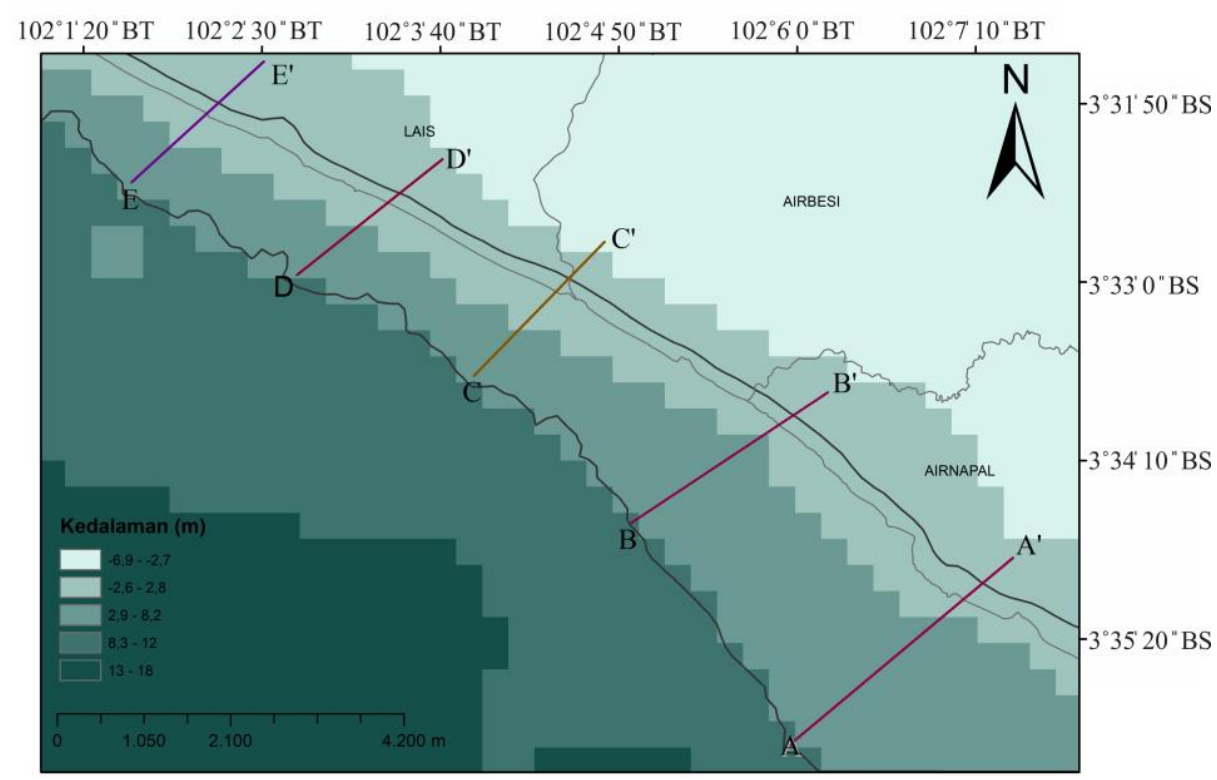

Gambar 5. Hasil image batimetri daerah penelitan dari data BIG.

Untuk melihat perbandingan bentuk batimetri secara nasional dan global, maka diperlihatkan gambaran (image) batimetri yang berasal dari data BIG (Gambar 5), GEBCO $450 \mathrm{~m}$ (Gambar 6), GEBCO 900 m (Gambar 7) dan ETOPO1 (Gambar 8). Hasil kontur batimetri dari pengambilan data di lapangan pada penelitian ini (Gambar 3) dapat dibandingkan dengan hasil kontur batimetri dari BIG dengan resolusi $25 \mathrm{~m}$ (Gambar 5). Garis kontur dari data penelitian BIG (Gambar 5) diperlihatkan bahwa kontur batimetri dari data ini tidak sejelas garis-garis kontur dari 
data pengambilan data di lapangan pada penelitian ini (Gambar 3). Selain itu dapat diketahui juga bahwa kedalaman dasar laut maksimum pada daerah penelitian dari data BIG hanya mencapai 8 $\mathrm{m}$ sedangkan kedalaman perairan maksimum jika menggunaka data batimetri dengan pengambilan secara langsung di lapangan mencapai $10 \mathrm{~m}$. Sementara itu hasil kedalaman dengan menggunakan data GEBCO $900 \mathrm{~m}$ dapat dilihat bahwa kedalaman maksimal dari seluruh daerah penelitian yaitu mencapai $32 \mathrm{~m}$ (Gambar 7).

Pengamatan batimetri dengan menggunakan ETOPO1 dengan resolusi $1850 \mathrm{~m}$ dapat dilihat bahwa kedalaman maksimum daerah penelitian hanya mencapai 2,8 m (Gambar 8), sedangkan pengambilan data secara langsung mencapai $10 \mathrm{~m}$. Kedalaman maksimum daerah penelitian dengan menggunakan BIG hanya mencapai $8 \mathrm{~m}$. Sementara kedalaman dari hasil data GEBCO dengan resolusi $450 \mathrm{~m}$ (Gambar 6), kedalaman laut maksimum mencapai $55 \mathrm{~m}$. Selain itu pengambaran batimetri dengan data ETOPO1 (Gambar 8) lebih nampak tidak beraturan bila dibandingkan dengan batimetri yang diperoleh pada penelitian ini. Hal ini dapat dimengerti karena resolusi spasial data batimetri mempengaruhi kualitass kontur dan informasi kedalaman serta akurasi data yang diperoleh.

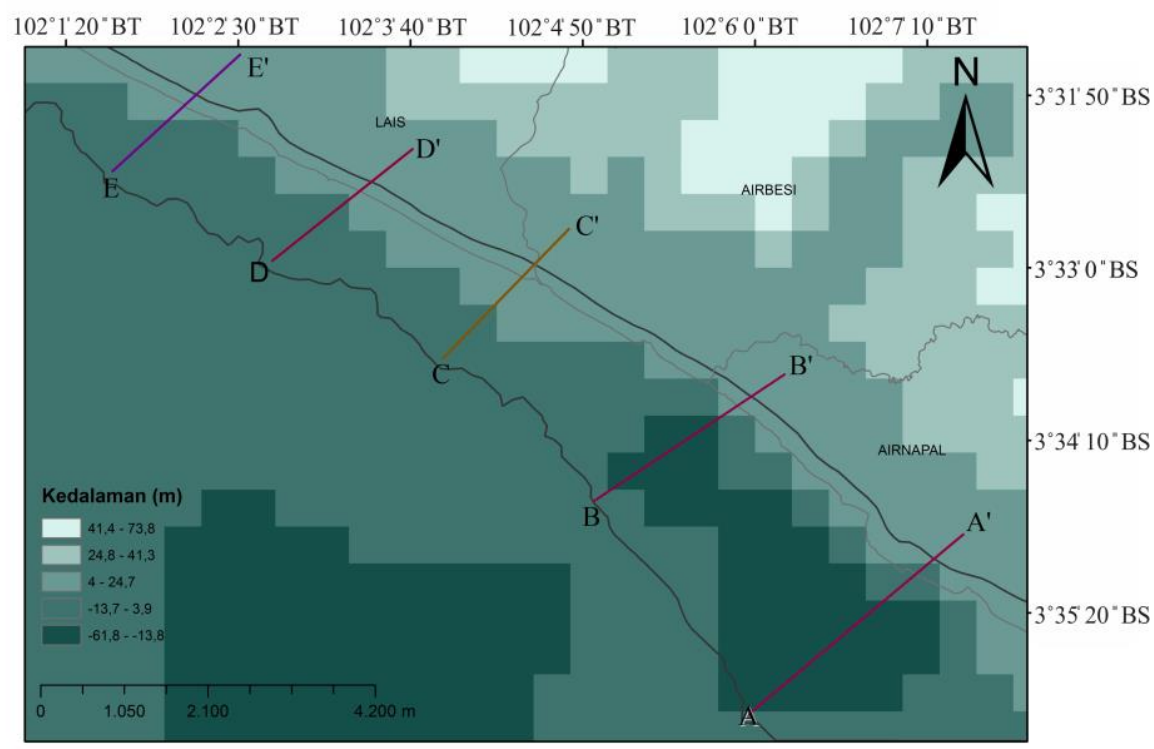

Gambar 6. Hasil image batimetri daerah penelitan dari data GEBCO $450 \mathrm{~m}$.

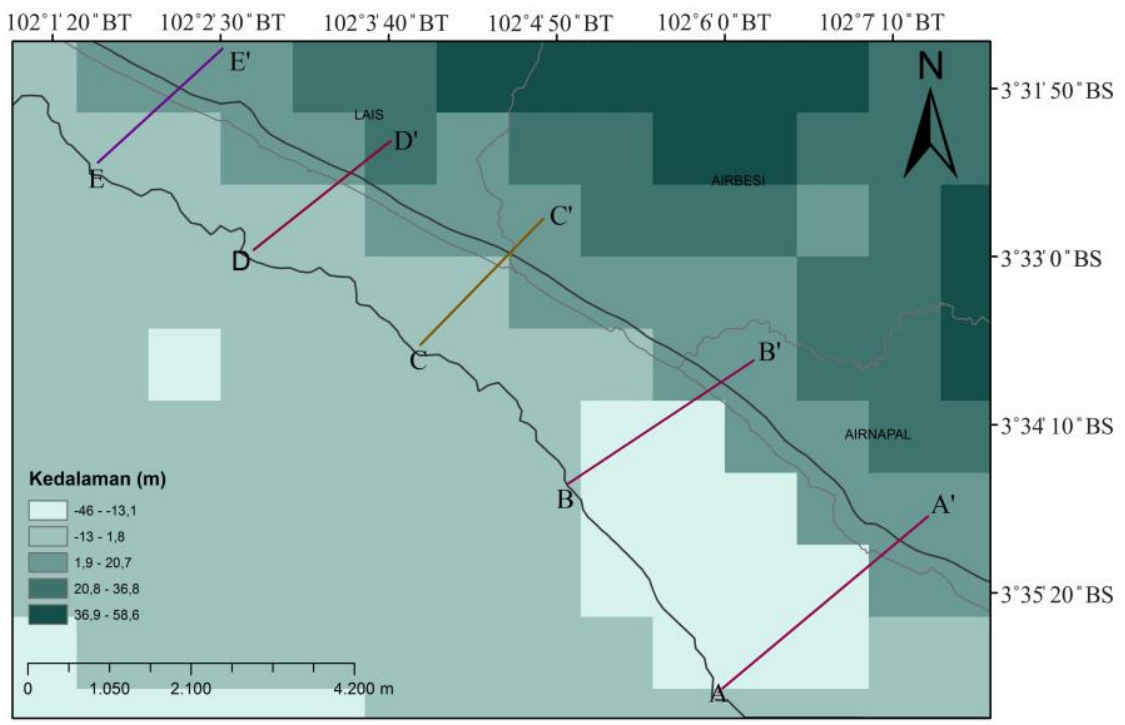

Gambar 7. Hasil image batimetri daerah penelitan dari data GEBCO $900 \mathrm{~m}$. 


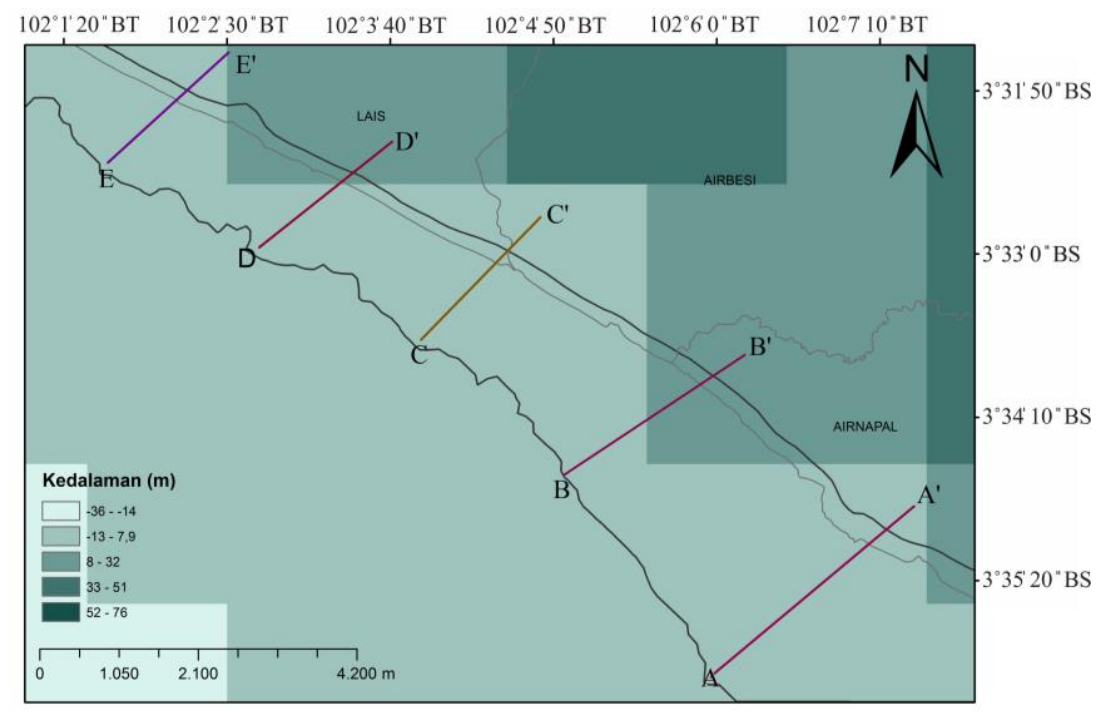

Gambar 8. Hasil image batimetri daerah penelitan dari data ETOPO1

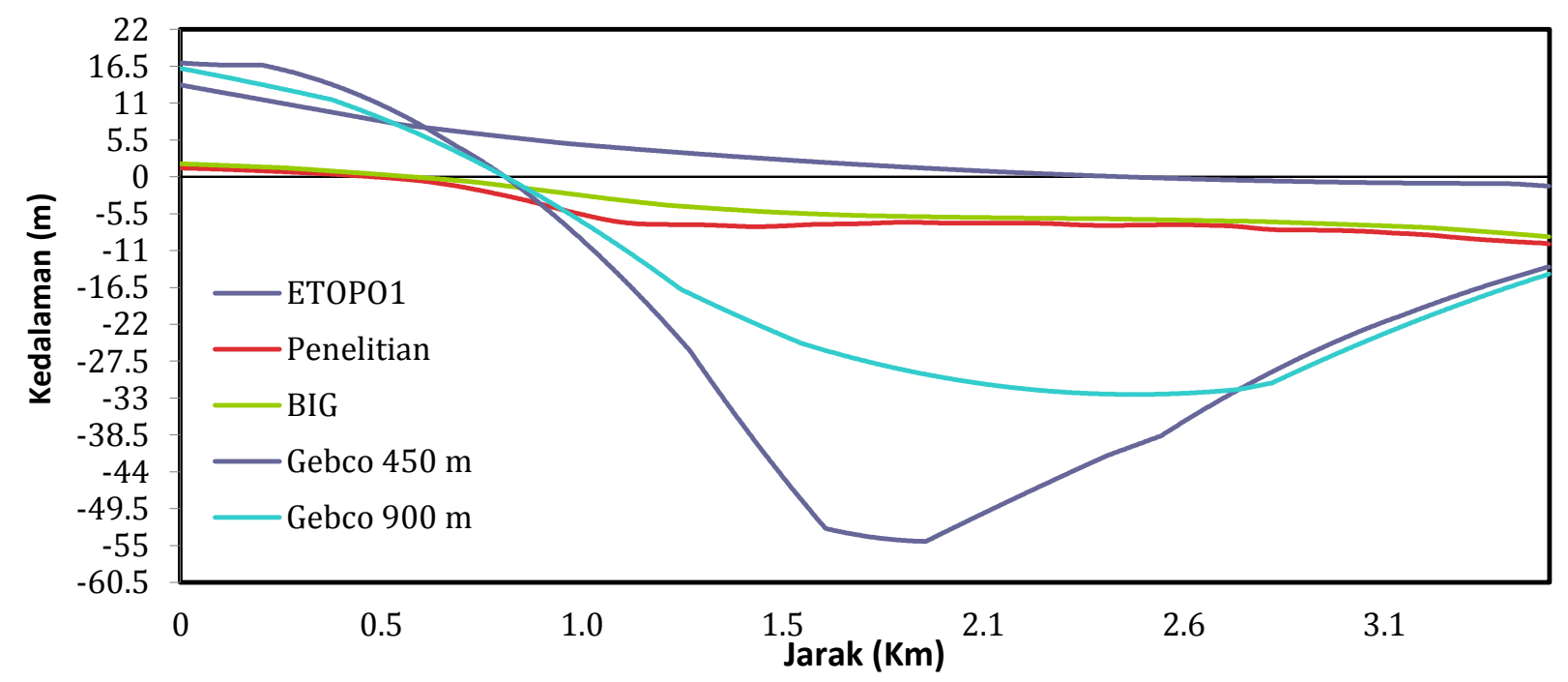

Gambar 9. Grafik Perbandingan Kemiringan Dasar Laut A-A'.

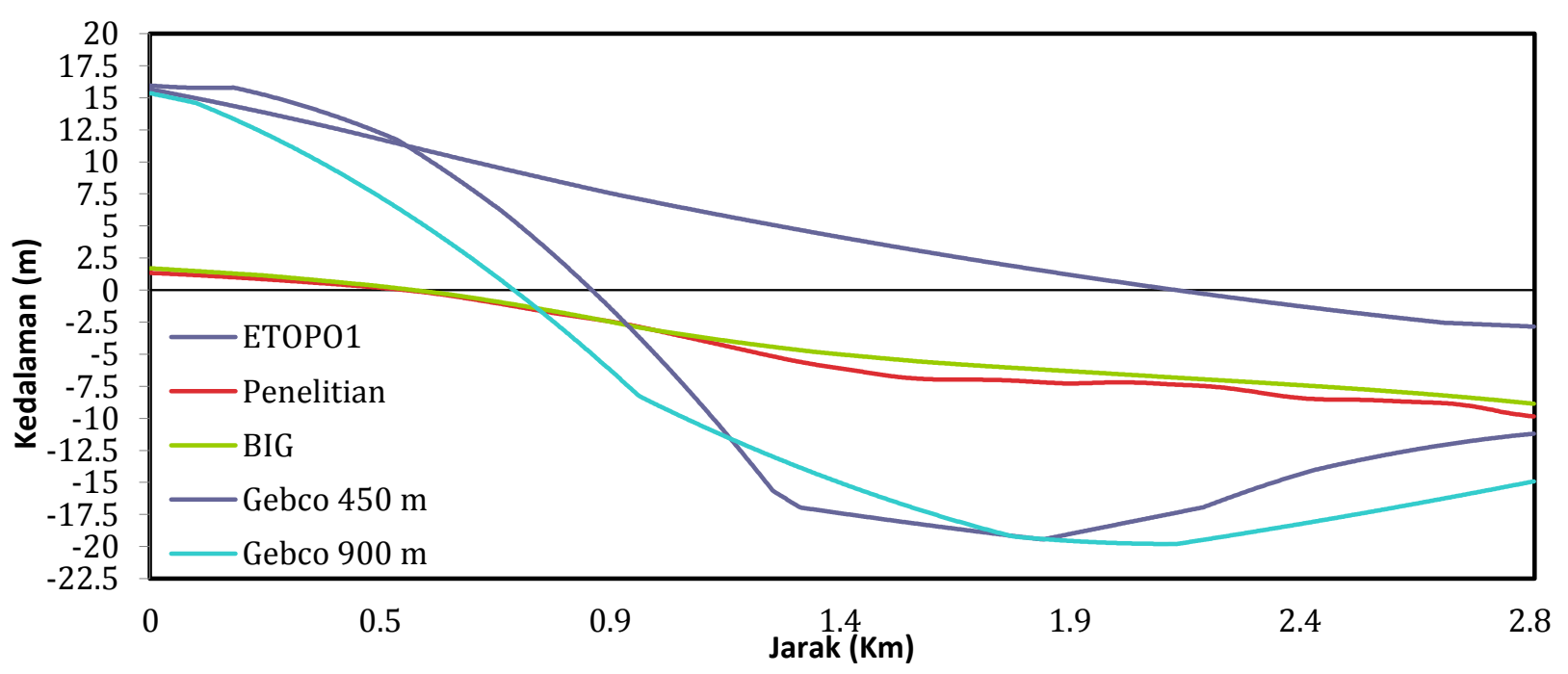

Gambar 10. Grafik Perbandingan Kemiringan Dasar Laut B-B'. 


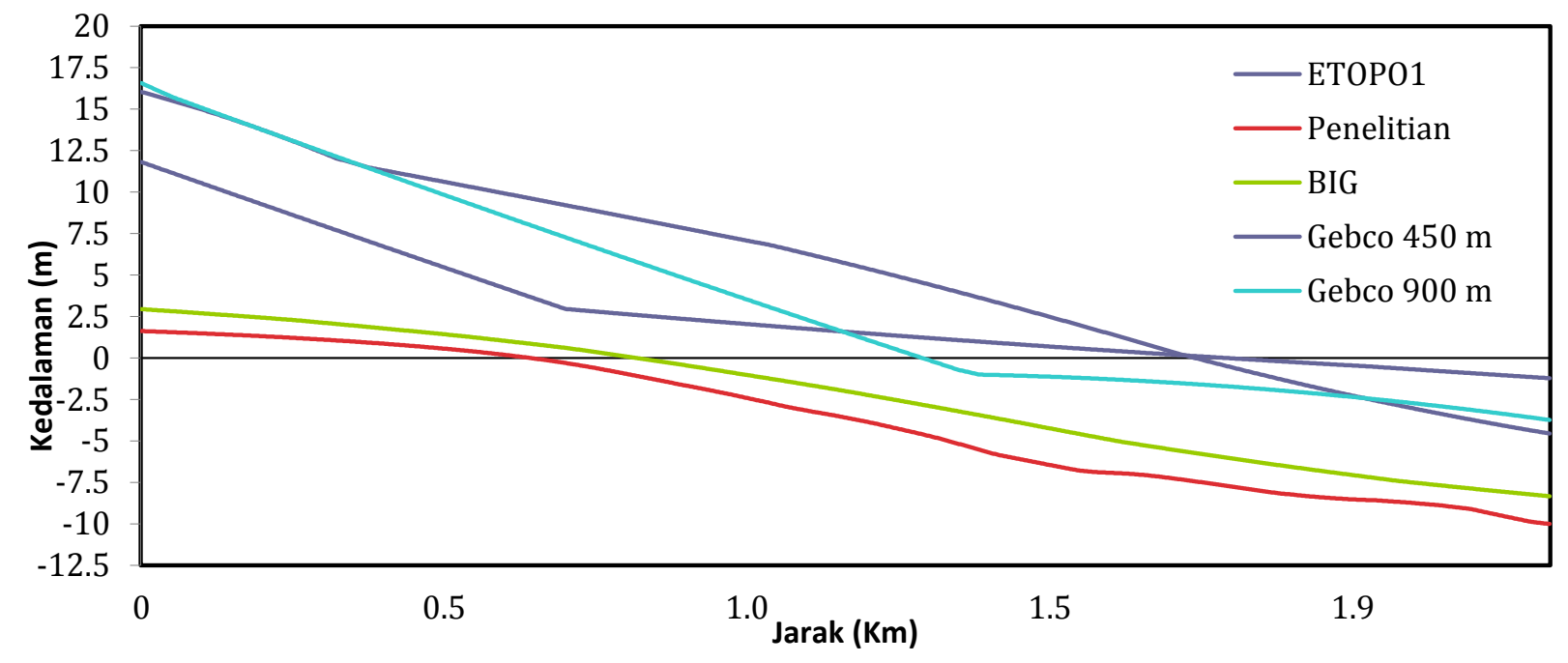

Gambar 11. Grafik Perbandingan Kemiringan Dasar Laut C-C'

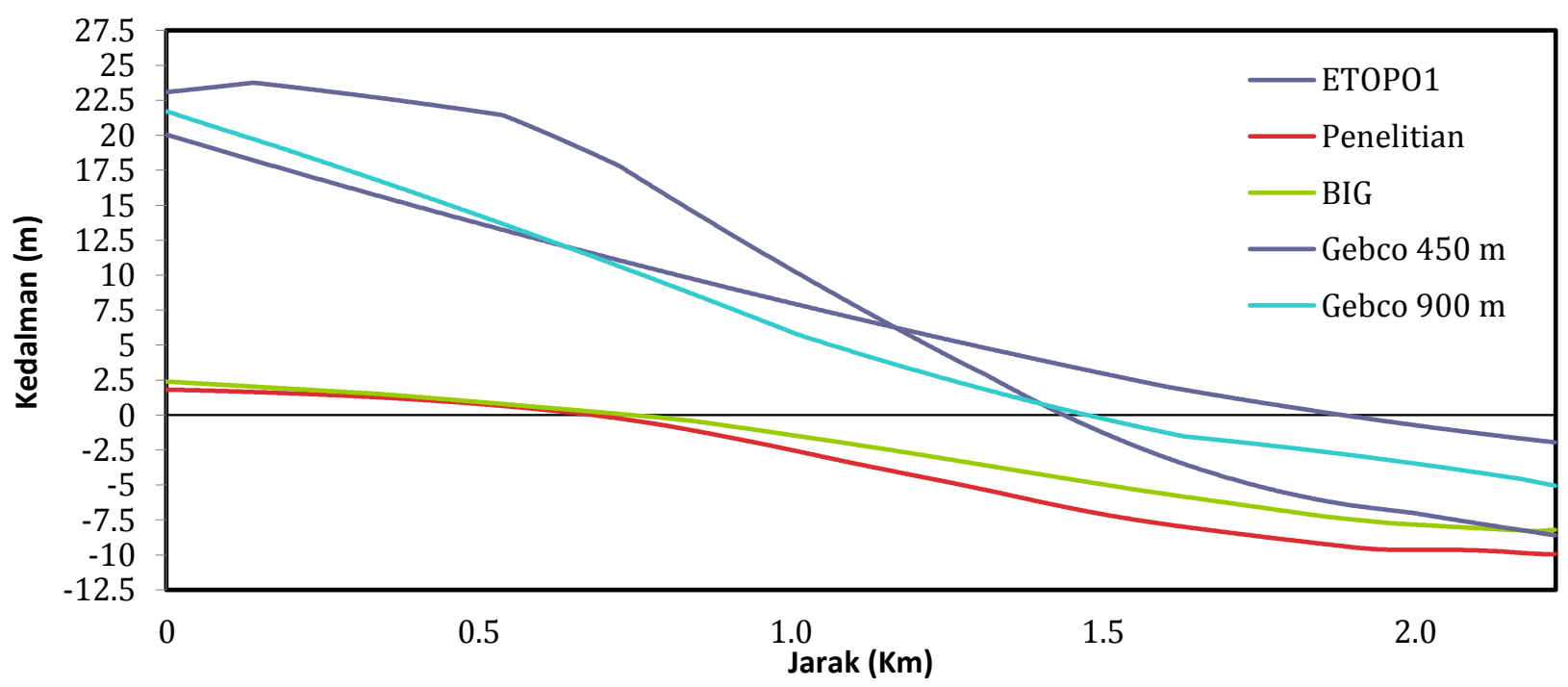

Gambar 12. Grafik Perbandingan Kemiringan Dasar Laut D-D'

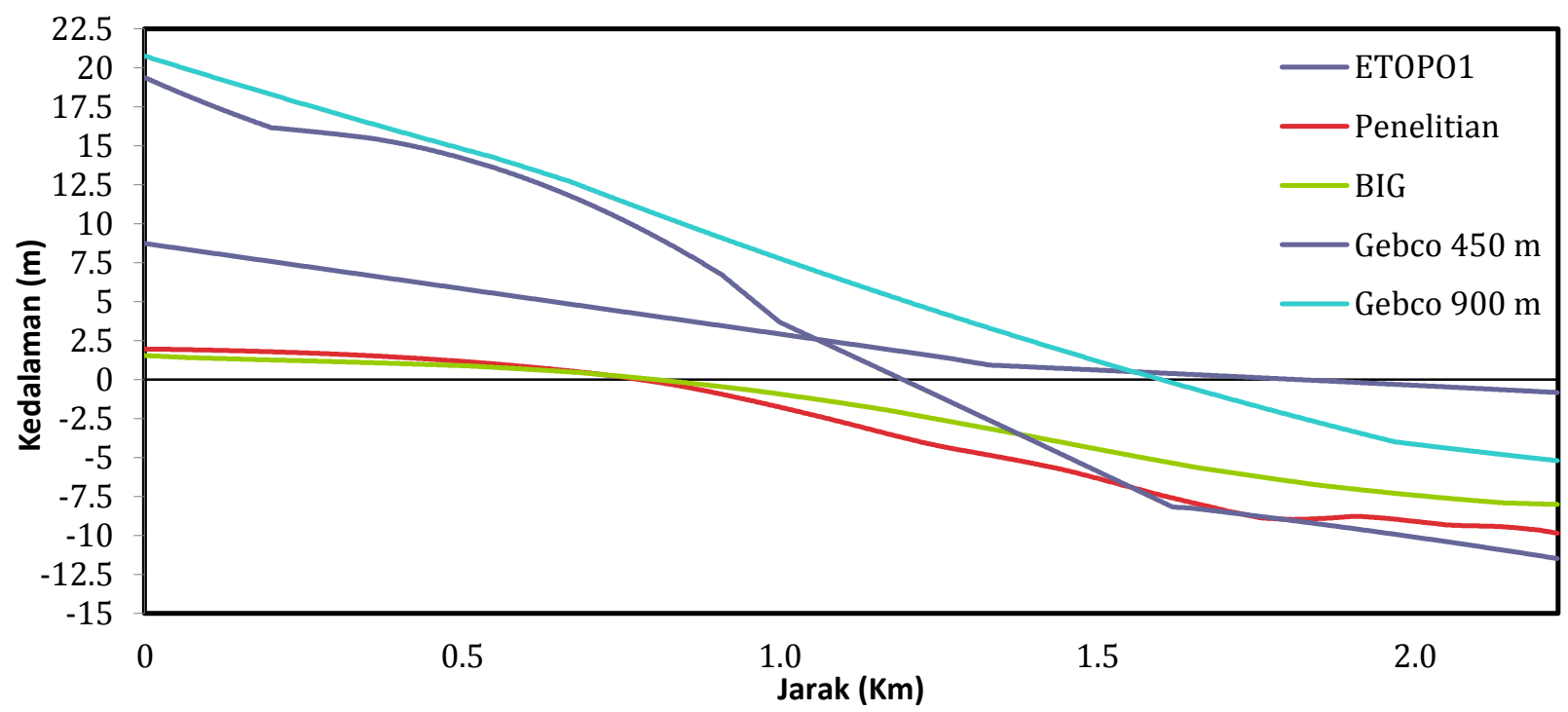

Gambar 13. Grafik Perbandingan Kemiringan Dasar Laut E-E' 
Bentuk morfologi pantai dan kemiringan pantai, maka dibuat 5 penampang kedalaman pada data batimetri yang terdiri dari penampang A-A', B-B', C-C', D-D' dan E-E' (Gambar 9-13). Berdasarkan Tabel 2 dan Gambar 6 dapat dilihat bahwa hasil penelitian batimetri yang terbaru yang dilakukan oleh Tozer et al., (2019) menunjukan hasil kedalaman yang jauh berbeda dengan hasil pengamatan penelitian langsung pada penelitian ini. Perbedaan yang sangat kontras dapat dilihat pada penampang A-A' dan B-B' (Gambar 9 dan Gambar 8). Penampang tersebut merupakan daerah yang mempunyai kedalaman paling maksimal diantara daerah penelitian lainnya, dengan kedalaman mencapai $55 \mathrm{~m}$ untuk penampang A$\mathrm{A}^{\prime}$, dan $20 \mathrm{~m}$ untuk penampang B-B'. Dengan demikian bahwa hasil penelitian terbaru Tozer et al., (2019) memiliki error yang sangat besar jika dibandingkan dengan keadaan yang sebenarnya di lapangan.

Tabel 2 menunjukkan bahwa kedalaman daerah penelitian sebesar $9,8 \mathrm{~m}$ dengan nilai kemiringan pada daerah $\mathrm{A}-\mathrm{A}^{\prime}$ sebesar $0,19^{\circ}$, pada daerah B-B' yaitu sebesar $0,24^{\circ}$, pada daerah C-C' sebesar $0,35^{\circ}$, pada daerah $\mathrm{D}-\mathrm{D}$ ' nilai kemiringan sebesar $0,37^{\circ}$, dan terakhir pada daerah E-E' sebesar $0,42^{\circ}$. Nilai kemiringan dasar laut semakin besar menuju arah utara atau section E-E'.
Sementara itu dengan menggunakan data batimetri BIG terlihat bahwa nilai kemiringan dasar laut juga menjadi lebih besar ke arah utara menuju Kecamatan Lais. Hal ini sama dengan hasil slice pengambilan data secara langsung menggunakan single beam echosounder. Kemiringan dasar laut dari data BIG dari section A-A' sampai dengan EE' bernilai dari $0,17^{\circ}-0,37^{\circ}$. Secara umum dapat dilihat bahwa hasil perhitungan kemiringan dan kedalaman dari data batimetri yang lain baik data dari BIG maupun dari data batimetri global yang lainnya mengalami perbedaan dengan data penelitian ini maupun dengan pengukuran langusung pada penelitian ini. Perbedaan ini terjadi karena masing-masing data set memiliki resolusi yang berbeda. Resolusi data batimetri yang tinggi akan memberikan akurasi yang lebih baik dan bias error yang kecil. Dengan resolusi data yang tinggi akan memberikan ukuran luasan yang kecil untuk per pixelnya, sehingga sangat memungkinkan menggambarkan batimetri sebuah perairan dengan sangat jelas dan detail.

Pada Tabel 3 diperlihatkan nilai kemiringan (slope) dasar laut pada setiap section A-A', B-B', C-C', D-D' dan E-E' untuk data pada penelitian ini, data BIG, GEBCO 450 m, GEBCO $900 \mathrm{~m}$ dan ETOPO1 dengan datum yang sama yakni MSL. Rata-rata nilai kemiringan dasar laut dari

Tabel 2. Hasil kedalaman laut untuk 5 penampang.

\begin{tabular}{ccccccc}
\hline \multirow{2}{*}{ No } & \multirow{2}{*}{ Slice } & \multicolumn{5}{c}{ Kedalaman maksimum $(\mathrm{m})$} \\
\cline { 3 - 7 } & & Penelitian ini & BIG & GEBCO 450 m & GEBCO 900 m & ETOPO \\
\hline 1 & A-A' & 9,8 & 8,7 & 55 & 32 & 1,2 \\
2 & B-B' & 9,6 & 8,6 & 19,2 & 19,8 & 2,8 \\
3 & C-C' $^{\prime}$ & 9,9 & 8,2 & 4,4 & 3,6 & 1,2 \\
4 & D-D' & 9,9 & 8,3 & 8,4 & 4,8 & 1,8 \\
5 & E-E' & 9,7 & 7,9 & 11,3 & 5,1 & 0,8 \\
\hline
\end{tabular}

Tabel 3. Perbandingan kemiringan dasar pantai di daerah Pantai Pasar Palik, Bengkulu Utara

\begin{tabular}{ccccccc}
\hline \multirow{2}{*}{ No } & \multirow{2}{*}{ Slice } & \multicolumn{5}{c}{ Kemiringan $\left(^{\circ}\right)$} \\
\cline { 3 - 7 } & & Penelitian ini & BIG & GEBCO 450 m & GEBCO 900 m & ETOPO \\
\hline 1 & A-A' & 0,19 & 0,18 & 1,39 & 0,57 & 0,07 \\
2 & B-B' & 0,24 & 0,22 & 0,57 & 0,54 & 0,23 \\
3 & C-C' & 0,35 & 0,34 & 0,51 & 0,21 & 0,22 \\
4 & D-D' & 0,38 & 0,34 & 0,60 & 0,39 & 0,34 \\
5 & E-E' & 0,43 & 0,38 & 0,65 & 0,48 & 0,22 \\
\hline
\end{tabular}




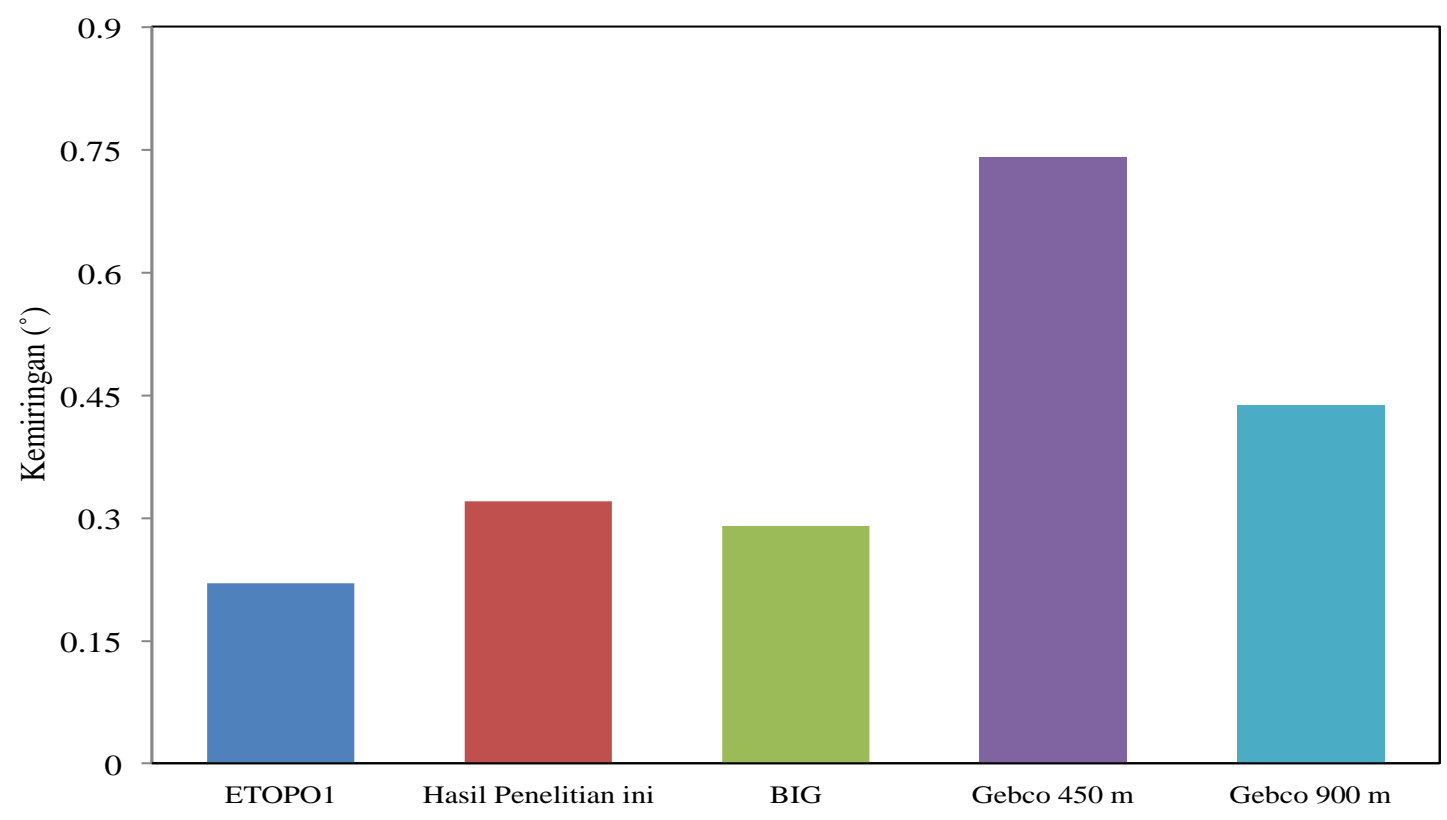

Gambar 14. Perbedaan Rata-rata Nilai Kemiringan Dasar Laut

kemiringan di daerah Pantai Pasar Palik, Bengkulu Utara dari data batimetri penelitian ini, data batimetri BIG dan data batimetri global yang lainnya diperlihatkan pada Gambar 14. Nilai kemiringan dasar laut dari semua slice (cross section) dapat dilihat bahwa data batimetri yang diperoleh pada penelitian ini sangat berbeda jika dibandingkan dengan data batimetri secara global. Namun jika dibandingkan dengan data batimetri BIG memiliki nilai kemiringan yang tidak jauh berbeda. Nilai rata-rata kemiringan dari hasil penelitian ini sebesar $0,32^{\circ}$, sedangkan nilai kemirngan rata-rata dasar laut dari data batimetri BIG sebesar $0,29^{\circ}$. Sementara itu nilai kemiringan rata-rata dasar laut dari data GEBCO $450 \mathrm{~m}$, GEBCO $900 \mathrm{~m}$ dan ETOPO berturut-turut adalah $0,74^{\circ}, 0,44^{\circ}$ dan $0,22^{\circ}$. Perbedaan kemiringan ini terjadi disebabkan oleh perbedaan kedalaman perairan dari data-data set yang berbeda yang dianalisis berdasarkan persamaan (2). Dari perbedaan kemiringan ini dapat dilihat bahwa resolusi data batimetri pada penelitian ini mempengaruhi bentuk morfologi dan nilai kemiringan dasar laut

Dari Gambar 14 dan Tabel 3 dapat diklasifikasikan berdasarkan klasifikasi lereng oleh Van Zuidam (1985) bahwa morfologi dasar laut Pantai Pasar Palik dan sekitarnya dikategorikan landai jika dilihat dari hasil perhitungan nilai slice setiap section baik data penelitian maupun data pembanding (BIG, GEBCO dan ETOPO1). Morfologi dasar laut yang dikategorikan landai menjadikan energi gelombang hilang sebahagian ketika menuju pantai sehingga terbentuklah arus sejajar pantai (longshore current). Menurut Triatmodjo, (1999) bahwa pantai dengan morfologi dasar laut rata (kemiringan $0-2^{\circ}$ ) run up gelombang energinya sebagian besar akan hilang saat diteruskan ke arah pantai dan sisanya diteruskan sebagai arus sejajar pantai (longshore current). Keberadaan arus sejajar pantai (longshore current) dapat mengerus bibir pantai di daerah pantai di Pasar Palik, Bengkulu Utara sehingga dapat terjadi abrasi bila strukutur geologi pantai yang rapuh. Hasil pengamatan arus laut di daerah Pantai Pasar Palik memperlihatkan adanya sejajar pantai (longshore current) menuju selatan tenggara ke Kota Bengkulu (anatar $150^{\circ}-180^{\circ}$ ) (Gambar 15).

Arus sejajar pantai (longshore current) yang terjadi disebabkan karena adanya gelombang yang pecah dengan sepanjang pantai yang membentuk sudut tertentu terhadap garis (Triatmodjo, 1999). Sebahagian energi gelombang gelombang datang langsung membentur tebingtebing pantai (Gambar 1) dan mengakibatkan lepasnya material-material yang mudah terkikis oleh gelombang. Material yang terkikis dan 


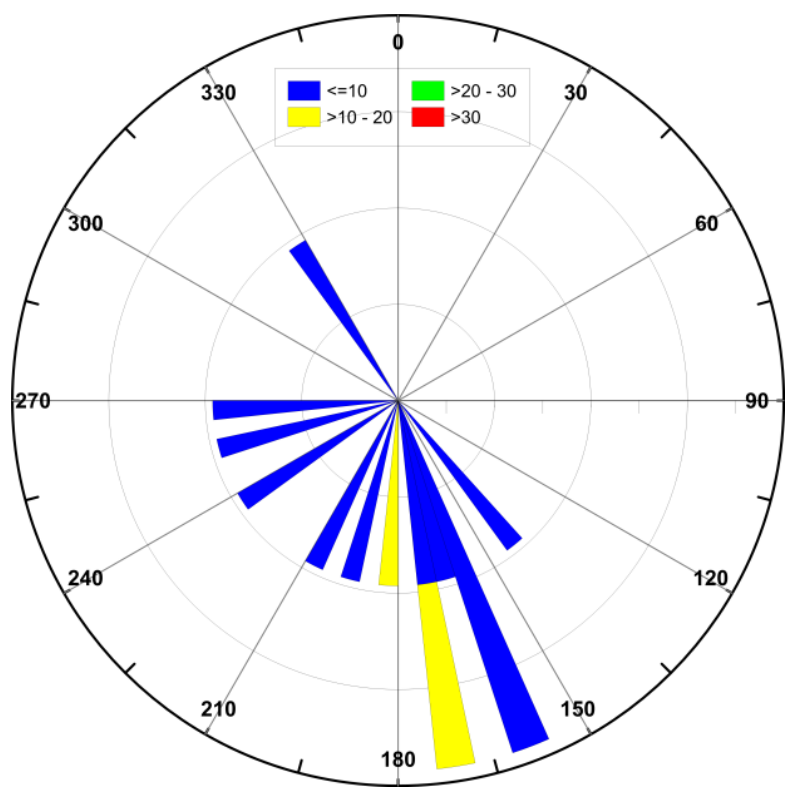

Gambar 15. Hasil pengamatan arus di daerah Pantai Pasir Palik, menunjukkan ada arus dominan searah garis pantai menuju arah selatan Kota Bengkulu. Satuan arus dalam $\mathrm{cm} /$ detik.

mudah lepas tersebut terbawa oleh arus sejajar pantai (longshore current) yang terbentuk dan ikut mempengaruhi morfologi dasar laut daerah pantai (Triatmodjo,1999).

Pada Gambar 4 terlihat juga bahwa terdapat anomali kedalaman laut di bagian selatan Pantai Pasar Palik. Anomali kedalaman tersebut berupa cekungan yang mempunyai nilai kedalaman mencapai $10 \mathrm{~m}$, ditengah-tengah kedalaman perairan yang mempunyai nilai kedalaman hanya berkisar 7-8 $\mathrm{m}$. Anomali tersebut diperkirakan terjadi akibat adanya muara sungai pada daerah tersebut yang berhadapannya laut. Hal ini mempengaruhi morfologi dasar laut akibat adanya dinamika gelombang laut dan arus sungai. Menurut Yuwono, (1994) morfologi laut di daerah muara sungai dipengaruhi parameter osenaografi seperti angin, arus laut, gelombang, debit sungai, dan pasang surut. Oleh karnea itu penelitian tentang hidro osenografi kedepan pada daerah ini sangat perlu dilakukan untuk melihat pengarhunya terhadap pembentukan morfologi pantai pada daerah ini.

\section{KESIMPULAN}

Telah dilakukan penelitian morfologi dasar laut di daerah Pantai Pasar Palik, Bengkulu Utara dengan survey batimetri menggunakan single beam echosounder. Dari hasil penelitian dapat disimpulkan bahwa kedalaman laut maksimum pada daerah ini $10 \mathrm{~m}$, lebih dalam bila dibandingan dengan menggunakan data BIG yang hanya mencapai $8 \mathrm{~m}$. Sementara itu hasil kedalaman dengan menggunakan data GEBCO resolusi $900 \mathrm{~m}$ mencapai kedalaman maksimal $32 \mathrm{~m}$. Selanjutnya pengamatan batimetri dengan menggunakan ETOPO1 dengan resolusi $1850 \mathrm{~m}$ mencapai kedalaman maksimum hanya mencapai 2,8 m, jauh lebih kecil bida dibandingkan dengan menggunakan data GEBCO dengan resolusi $450 \mathrm{~m}$ yang mencapai kedalaman laut maksimum sampai $55 \mathrm{~m}$. Kemiringan dasar laut dengan survey batimetri menggunakan single beam echosounder sebesar $0,32^{\circ}$, berada dalam interval kemiringan dasar laut dasar laut dengan menggunakan data set yang lain yakni $0,29^{\circ}-0,74^{\circ}$. Berdasarkan hasil ini, maka dapat disimpulkan juga bahwa morfologi dasar laut Pasar Palik dan sekitarnya dalam kategori yang landai. Selanjutnya, mengingat bahwa morfologi bawah laut di daerah pantai dapat dipengaruhi oleh gelombang laut, arus sejajar pantai (longshore current), pasang surut serta debit muara sungai, maka kedepan sangat diperlukan penelitian lanjutan untuk pengamatan data-data oseanografi tersebut untuk melihat dinamika perubahan morfologi dasar laut pada daerah ini secara temporal.

\section{UCAPAN TERIMA KASIH}

Penulis mengucapkan terimakasih kepada kru kapal yang telah bersedia menyediakan kapal untuk pengambilan data di lapangan. Penulis juga 
mengucapkan terima kasih kepada mahasiswa Jurusan Fisika yang telah banyak membantu dalam pengambilan data di lapangan. Ucapan terima banyak terima kasih juga ditujukan kepada Pusat Penelitian Ocenografi (P2O) Lembaga Ilmu Pengetahuan Indonesia (LIPI) yang telah mengijinkan penggunaan alat Single Beam Echosounder Bathy 500 Dual Frequency. Penelitian ini didanai oleh proyek Demand Driven Research Grant (DDRG) tahun 2018 melalui kegiatan Coral Reef Rehabilitation and Management Program Coral Triangle Initiative (COREMAP-CTI), LIPI.

\section{DAFTAR PUSTAKA}

Amante, C. \& Eakin, B.W., 2009. ETOPO1 1 ArcMinute Global Relief Model: Procedur, Data Source and Analysis. NOAA Technical Memorandum NESDIS NGDC-24, 19 pp, March 2009.

Hutchinson, M.F., 1989. A New Procedure For Gridding Elevation And Stream Line Data With Automatic Removal ff Spurious Pits. Journal of Hydrology, 106(3-4):211-232.

Lowest Astronomical Tide Pada Peta Dasar Kelautan Berdasarkan Variasi Panjang Periode Pengamatan. ITB Indonesian Journal of Geospatial, 5 (2): 35-50
Lubis A.M, \& Samdara, R., 2016. Kajian abrasi pantai di daerah Bengkulu Utara. Laporan Penelitian Hibah Bersaing, DIKTI. 48p

Sunamura, T., 2015. Rocky coast processes: with special reference to the recession of soft rock cliffs, Proc Jpn Acad Ser B Phys Biol Sci. 91(9):481-500. doi: 10.2183/pjab.91.481

Tozer, B, Sandwell, D.T., Smith, W.H.F., Olson, C., Beale, J.R. \& Wessel, P., 2019. Global bathymetry and topography at 15 arc sec: SRTM15+. Earth and Space Science. 6:18471864. doi :10.1029/2019EA000658

Triatmodjo, B., 1999. Teknik Pantai. Penerbit Gramedia Pustaka Utama, Jakarta. 397p

Van Zuidam R.A., 1985. Aerial PhotoInterpretation in Terrain Analysis and Geomorphology Mapping. The Hague: Smith Publisher, ITC. $441 \mathrm{p}$

Weatherall, P., Marks, K., Jakobsson, M., Schmitt, T., Tani, S., Arndt, J.E., Rovere, M., Chayes, D., Ferrini, V. \& Wigley, R., 2015. A new digital bathymetric model of the world's oceans. Earth and Space Science, 2:416-430.

Yuwono, N., 1994. Perancangan Bangunan Jetty. Laboratorium Hidraulika dan Hindrologi. PAU-IT-UGM. Yogyakarta. 189p 